\title{
Vitamin D and Type 2 Diabetes Mellitus: Indian Perspectives
}

Shilpa Balaji Asegaonkar ${ }^{*}$

Government Medical College, Aurangabad, India

*Corresponding author: Shilpa Balaji Asegaonkar, Associate Professor, Government Medical College, Aurangabad, India, Tel: $919420763430 ;$ Fax: 912402402418; Email: sbasegaonkar73@gmail.com

Rec date: April 26, 2016; Acc date: July 09, 2016; Pub date: July 18, 2016

Copyright: (C) 2016 Asegaonkar SB. This is an open-access article distributed under the terms of the Creative Commons Attribution License, which permits unrestricted use, distribution, and reproduction in any medium, provided the original author and source are credited.

\begin{abstract}
Deficiency of vitamin $D$ is emerging as one of the important nutritional risk factors for development of insulin resistance (IR) and Type 2 Diabetes Mellitus (T2DM). It is also observed to be associated with poor glycemic control and progression of complications among diabetics. In India, in spite of adequate sunlight exposure throughout year, several reports documented prevalent finding of deficiency of vitamin D. With the context of rising surge of T2DM and hypovitaminosis $D$ among Indians, relation between vitamin D and T2DM and related studies have been reviewed in the present article.
\end{abstract}

Vitamin D plays important roles in the metabolism of glucose. It directly stimulates insulin secretion from beta cells of pancreas. It increases intracellular calcium levels, which attenuates insulin synthesis. Also it improves insulin sensitivity in peripheral muscle and fats cells. T2DM is a state of chronic low-grade chronic inflammation and being anti-inflammatory in nature, vitamin $\mathrm{D}$ exerts beneficial effects on glycemic control and prevention of complications.

Current data about vitamin D status in T2DM is based on small sporadic studies from different regions of India. Researchers have reported conflicting results about the association of hypovitaminosis D with development of T2DM and its complications. This warrants an urgent need of population based; large sample sized prospective studies to prove the role of vitamin $\mathrm{D}$ in every stage, from prevention to management.

Keywords: Type 2 Diabetes Mellitus; Vitamin D; Prediabetes; and Insulin resistance

\section{Background}

Type 2 Diabetes Mellitus (T2DM) is the most prevalent chronic metabolic disorder worldwide. It is caused due to impaired glucose tolerance caused by Insulin resistance and beta cell failure. T2DM is the significant cause of premature morbidity and mortality imposing enormous socioeconomic burden globally [1]. As per the current prevalence and trend of T2DM, International Diabetes Federation (IDF) predicted 592 millions people will have T2DM by 2035 worldwide [2]. Prevalence of T2DM is escalating at rapid pace in India due to westernization of lifestyle. As per IDF report, the prevalence of T2DM will increase to 101.2 million by 2030 among Indians [3].

Several etiological factors including genetic, environmental, lifestyle and nutritional have been implicated in the causation of T2DM. One of the important emerging nutritional risk factors recognized for the development of insulin resistance (IR) and T2DM is deficiency of vitamin $\mathrm{D}$. Also it has been proposed to be associated with worsening of glycemic control and progression of complications among T2DM individuals [4]. In spite of adequate sunlight exposure throughout year, several studies documented deficiency of vitamin $\mathrm{D}$ as most prevalent finding among Indians [5]. With this context of rising surge of T2DM and hypovitaminosis $\mathrm{D}$ among Indians, relation between vitamin $\mathrm{D}$ and T2DM and related recent studies published from India have been reviewed in the present narrative review article.

Skeletal manifestations of vitamin D deficiency are well known. But recently, the evidences have shown hypovitaminosis D as a risk factor in the causation of various noncommunicable, metabolic disorders. Numerous research studies documented association of insufficiency/ deficiency of Vitamin D with T2DM. Beneficial effects of administration of vitamin $\mathrm{D}$ in improving insulin sensitivity among diabetics are also reported. But whether supplementation of vitamin $\mathrm{D}$ prevents development of T2DM and its complications is not confirmed due to inconsistent results from clinical trials. Differences in race, body mass index, glycemic status, and exposure to sunlight, inadequate dose, and low compliance could be the possible reasons for such discordance observations. Baseline low levels of vitamin D, poor glycemic control and insufficient post hoc analysis power may also be probable factors for such results [6,7].

Vitamin D plays important roles in the metabolism of glucose. It directly stimulates insulin secretion from beta cells of pancreas. It increases intracellular calcium levels, which attenuates insulin synthesis. Also it improves insulin sensitivity in peripheral muscle and fats cells. T2DM is a state of chronic low-grade chronic inflammation. Because of anti-inflammatory nature, vitamin D exerts beneficial effects on glycemic control and helps in prevention of complications of T2DM [8].

\section{Vitamin D and T2DM: An Indian Scenario}

India is facing concurrent epidemics of T2DM and hypovitaminosis $\mathrm{D}$ due to urbanization and industrialization. Despite of adequate sunshine throughout the year, hypovitaminosis D is commonly seen among Indians across all age groups in urban as well as rural regions. It is associated with IR which progress towards T2DM and its subsequent complications. Indian researchers investigated association of vitamin D deficiency with IR, T2DM, glycemic control and progression of 
complications among diabetics. After extensive literature search on PubMed and Google scholar search engine, Indian studies evaluating association of vitamin D with T2DM were selected in the present review. One of the most important limitations among these studies is small sample size. Hence these studies could not reach the statistical significance. But vitamin D deficiency has been identified as an independent adjunctive risk factor for T2DM. Following papers were studied to evaluate the relation of vitamin D status with T2DM among Indians (Table 1).

\begin{tabular}{|c|c|c|c|}
\hline $\begin{array}{l}\text { Authors and reference } \\
\text { number }\end{array}$ & Study design & $\begin{array}{l}\text { Number and characteristics of } \\
\text { Subjects }\end{array}$ & Main outcome \\
\hline Kotwal et al. [9] & Case control & $\begin{array}{l}102 \text { newly detected and similar } \\
\text { controls. North Indian subjects }\end{array}$ & $\begin{array}{l}81 \% \text { cases and } 67 \% \text { controls had deficiency. } 16.2 \% \text { diabetics and } 2.5 \% \\
\text { controls had severe deficiency. Mean vitamin } D \text { in cases } 18.81+/-15.18 \text { vs } \\
28.26+/-18.89 \text { in controls }(p<0.000) \text { Significant negative correlation with } \\
\text { fasting blood glucose and } H b A 1 c \text {. }\end{array}$ \\
\hline Dutta et al. [10] & Cross sectional & $\begin{array}{l}157 \text { prediabetes subjects, } 42 \mathrm{~T} 2 \mathrm{DM} \\
\text { and } 28 \text { healthy controls. }\end{array}$ & $\begin{array}{l}\text { Severe deficiency }(<10 \mathrm{ng} / \mathrm{ml}) \text { in } 14.65,7.14 \% \text { in diabetics and control. } \\
\text { Deficiency/insufficiency in } 73.25 \% \text { prediabetes, } 66.6 \% \text { diabetes, } 78.7 \% \\
\text { healthy subjects. Vitamin } D<10 \mathrm{ng} / \mathrm{ml} \text { inversely correlated with highest IR- } \\
\text { HOMA2IR } 2.04+/-0.26, r=0.33 \mathrm{p} 0.008 \text {. Positive correlation with insulin } \\
\text { sensitivity QUICKI r } 0.39, \mathrm{p} 0.002 \text {. No correlation with estimated beta cell } \\
\text { mass. }\end{array}$ \\
\hline Mukherjee [8] & Cross sectional & 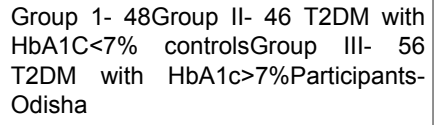 & $\begin{array}{l}\text { Significant deficiency in-group III }(p<0.001) \text {. Negative correlation of } \\
\text { vitamin } D \text { with } \mathrm{HbA} 1 \mathrm{c} \text { - poor glycemic control }(r=-0.96)\end{array}$ \\
\hline Sheth et al. [11] & $\begin{array}{l}\text { Prospective Cross } \\
\text { sectional }\end{array}$ & $\begin{array}{l}429 \text { T2DM and } 483 \text { healthy control } \\
\text { urban western India }\end{array}$ & $\begin{array}{l}\text { Deficiency in both groups without any statistically significant difference. } \\
\text { No association with HbA1c and HOMA-IR in both groups. ( } 0.057,0.257 \\
\text { vs } 0.675,0.647 \text { ) }\end{array}$ \\
\hline Mohpatra [12] & Case control & $\begin{array}{l}68 \text { controls and } 68 \text { T2DM with and } \\
\text { without complications from Odisha }\end{array}$ & $\begin{array}{l}\text { More deficiency in complicated DM (mean 13.14+/-1.45) than } \\
\text { uncomplicated }(19.94+/-2.4) \text { and controls (mean 33+/-3.3). Inverse } \\
\text { association of vitamin D with } \mathrm{HbA1c}(r=-0.883, p<0.001)\end{array}$ \\
\hline Bid et al. [13] & Case control & $\begin{array}{l}100 \text { T2DM, } 160 \text { controls North Indians } \\
\text { to study Vitamin D receptor (VDR) } \\
\text { gene polymorphism and risk of T2DM }\end{array}$ & $\begin{array}{l}\text { VDR gene polymorphism in combination with genotypes FfBbTt and } \\
\text { FFBbtt associated with increased risk of T2DM. But there was no } \\
\text { significant difference in rest of genotypes and VDR gene polymorphism } \\
\text { with cases and controls. }\end{array}$ \\
\hline Chaudhari et al. [14] & Case control study & $\begin{array}{l}\text { Total- } 155 \text { subjects Non-diabetic ( } 39) \text {, } \\
\text { only T2DM ( } 46) \text { Pulmonary Koch's } \\
\text { with ( } 40) \text { and without T2DM }(30) \text {. }\end{array}$ & $\begin{array}{l}\text { Severe deficiency of vitamin D in pulmonary Koch's only }(93.5 \%) \text {, Koch's } \\
\text { with T2DM }(87.5 \%) \text {, only T2DM }(80.5 \%-\text { mean } 19.42+/-11.32) \text { and } \\
\text { healthy }(61.5 \% \text { mean } 29.47 \%) . \quad P<0.001 \text { Non-significant difference } \\
\text { statistically. }\end{array}$ \\
\hline Daga et al. [15] & Case control & $\begin{array}{l}72 \text { newly diagnosed youth onset }(<25 \\
\text { years) type } 1 \mathrm{DM}(13) \text { and T2DM }(58) \\
\text { and healthy controls }\end{array}$ & $\begin{array}{l}\text { Severe deficiency in T1DM than T2DM. Mean vitamin D cases- } 7.8+/-1.2 \\
\mathrm{ng} / \mathrm{ml} \text {, controls- } 16.64 \mathrm{ng} / \mathrm{ml}(\mathrm{p} \text { value } 0.26) 91.1 \% \text { cases and } 58.5 \% \\
\text { normal individuals were deficient. No correlation of vitamin D levels with } \\
\text { clinical and biochemical parameters, HbA1c. }\end{array}$ \\
\hline Doddamani [16] & Cross sectional & $\begin{array}{l}\text { Newly diagnosed cases of T2DM } \\
(n=50)\end{array}$ & $\begin{array}{l}70 \% \text { patients had vitamin } D<20 \mathrm{ng} / \mathrm{ml} .(p<0.001) \text { Inverse correlation with } \\
\mathrm{HbA} 1 \mathrm{c} \text { and fasting plasma glucose. }(p-0.006,<0.001 \text { respectively })\end{array}$ \\
\hline Bajaj et al. [17] & Case control & $\begin{array}{l}74 \text { T2DM cases and } 70 \text { age and sex } \\
\text { matched healthy normoglycemic } \\
\text { controls }\end{array}$ & $\begin{array}{l}\text { Deficiency of vitamin } D \text { in } 13.51 \% \text { of diabetics and } 28.57 \% \text { in controls. } \\
\text { statistically significant inverse correlation betweem vitamin } D \text { and total } \\
\text { cholesterol }(-0.279) \text { and low density lipoproteins }(-0.297) \text {. }\end{array}$ \\
\hline Latha [18] & Cross sectional & $51 \mathrm{~T} 2 \mathrm{DM}$ and 51 healthy controls & $\begin{array}{l}\text { vitamin D positively associated with high density lipoproteins }(r=0.697) \\
\text { and inversely with fasting blood sugar and triglycerides (at } p<0.01 \\
r=-0.79,-0.435 \text { respectively) among cases. }\end{array}$ \\
\hline Tandon et al. [19] & Cross sectional & $\begin{array}{l}312 \text { Post-menopausal women } \\
\text { evaluated for deficiency of vitamin D }\end{array}$ & $\begin{array}{l}\text { Results failed to establish correlation of vitamin } D \text { deficiency with } \\
\text { existence of T2DM may be due to small sample size Correlation between } \\
\text { vitamin } D \text { deficiency and raised blood glucose was non-significant } \\
(p=0.324) \text {. }\end{array}$ \\
\hline Kumar et al. [20] & Cross sectional & $\begin{array}{l}50 \text { T2DM cases categorized into } 3 \\
\text { groups according to vitamin D levels. }\end{array}$ & $\begin{array}{l}\text { Significant deficiency in cases in relation to age of onset }(p<0.001) \text {, } \\
\text { HbA1c }(p-0.006) \text {, blood sugar }(p-0.001) \text { while difference in relation to BMI } \\
\text { and duration of T2DM ( }-0.109,0.666 \text { respectively) non-significant. }\end{array}$ \\
\hline
\end{tabular}

Table 1: vitamin D status with T2DM among Indians.

Seth et al. could not establish role of deficiency of vitamin D in glycation of hemoglobin and IR, although deficiency was prevalent in individuals with and without T2DM [11]. Niti Agrawal et al. investigated association of serum hydroxyvitamin D with markers of 
IR among postmenopausal women. They found inverse correlation between vitamin $\mathrm{D}$ and BMI ( $\mathrm{r}=-0.234 \mathrm{p}-0.047)$ and HOMAIR $(\mathrm{r}=-0.237 \mathrm{p}-0.047)$. On adjustment of BMI, association with HOMAIR was lost statistical significance [21]. Deep Dutta et al. found statistically significant inverse correlation of vitamin $D$ with IR (HOMA2IR 2.04+/- $0.67 \mathrm{r}$ 0.33) and positive correlation with Insulin sensitivity (QUICKI $\mathrm{r}=0.39$, p-0.002). People with severe deficiency had highest IR. But no correlation could be observed between vitamin $\mathrm{D}$ and estimated beta cell mass. The study reported worsening of IR in Indians with prediabetes [10]. In Indian Diabetes prevention program-1 study, $18 \%$ annual risk of progression of prediabetes to diabetes has been reported [22]. So longitudinal prospective studies with intervention of supplementation of vitamin D are strongly warranted among Indian population.

\section{Vitamin D and T2DM}

Active metabolite of Vitamin D $(1,25$-dihydroxy vitamin D3) is involved in normal endocrine function of pancreas. Vitamin D and VDR complex play role of transcription factor in regulating secretion of beta cells function of insulin secretion [14]. Kota supplemented vitamin $\mathrm{D}$ to pulmonary tuberculosis patients with uncontrolled diabetes. They reported improval of glycemic control after supplementation suggesting that vitamin $\mathrm{D}$ could be an adjunct therapy in tuberculosis patients with T2DM [21-23].

Hypovitaminosis D is commonly seen in obesity, which is most important cause of prediabetes. In obesity, adipose tissues store 25hydroxy vitamin D making it biologically unavailable resulting in depletion of calcitriol and rise in PTH. This in turns increases intracellular calcium in adipocytes stimulating lipogenesis with subsequent weight gain and impaired glucose intolerance [24] Deficiency of vitamin D favors systemic inflammation and worsens glycemic control among diabetics enhancing their cardio-metabolic risk [25]. Shore-Lorenti et al. performed systematic review of literature and found moderate level evidence for association of sunlight exposure with T2DM [26].

Action of vitamin D and its active metabolite, 1,25-di(OH)-vitamin $\mathrm{D}$ has been well recognised as an important regulator of bone health and calcium homeostatsis. It is a part of "Calcium-Vitamin DParathyroid hormone" endocrinal axis. Apart from extra-skeletal functions, it regulates around 200 genes function. Since last decade, its role in the causation of various cardio-metabolic disorders, IR, T2DM and malignancies has been widely studied. Inadequate direct exposure to sunlight, increased skin pigmentation, environmental pollution, obesity and malabsorption have been proposed as possible reasons for vitamin D deficiency in India even though it's tropical country [27]. There is steep rise in prevalence of T2DM by 10 -fold in urban as well as rural parts of India. Sedentary lifestyle and high intake of refined carbohydrates have been identified as important predisposing factors [28]. Decreased physical activity is also one of the causes for hypovitaminosis D. So it's a common factor in etiology of both, T2DM and vitamin D deficiency. Physical exercise would improve vitamin D status as well as prevent development and progression of T2DM [29]. Vitamin D modulates expression of insulin receptors genes and insulin secretion. So it's a new ray of hope in the management of T2DM. Possible mechanisms to find link between hypovitaminosis $\mathrm{D}$ and T2DM have been investigated by researchers. Activation of vitamin D receptor and calcium homeostasis impair beta cell function of pancreas causing IR and its subsequent effects [30].

\section{Conclusion}

Current data about vitamin D status in T2DM is based on small sporadic studies from different regions of India. Researchers have reported conflicting results about the association of hypovitaminosis D with development of T2DM and its complications. This warrants an urgent need of robust evidence from population based; large sample sized prospective studies to prove the role of vitamin D in every stage of T2DM, from prevention to its management. Supplementation of vitamin D for prevention of T2DM, and its complications, halting progression from prediabetes to $\mathrm{T} 2 \mathrm{DM}$, and improving glycemic control is of utmost importance. If these roles could be established by statistically significant findings, vitamin $\mathrm{D}$ will remain at the cornerstone of T2DM management and prevention of morbidity and mortality. It could minimize enormous socioeconomic healthcare burden.

\section{References}

1. Stumvoll M, Goldstein B, van Haeften TW (2005) Type 2 diabetes: principles of pathogenesis and therapy. Lancet 365: 1333-1346.

2. International Diabetes Federation (2013) IDF Diabetes Atlas. (6thedn), International Diabetes Federation.

3. IDF: One adult in ten will have diabetes by 2030. IDF Press release 2011.

4. Pittas AG, Dawson-Hughes B (2010) Vitamin D and Diabetes. J Steroid Biochem Mol Biol 121: 425-429.

5. Ritu G, Ajay G (2014) Vitamin D Deficiency in India: Prevalence, Causalities and Interventions. Nutrients 6: 729-775.

6. Reis JP, Mühlen VD, Silverstein DK, Wingard DL, Connor EB (2007) Vitamin D, parathyroid hormone levels, and the prevalence of metabolic syndrome in community-dwelling older adults. Diabetes Care 30: 1549-1555.

7. Mitri J, Muraru MD, Pittas AG (2011) Vitamin D and type 2 diabetes: a systematic review. European Journal of Clinical Nutrition 65: 1005-1015.

8. Brijesh M, Saurav P (2014) Prevalence of vitamin D deficiency in type-2 Diabetes Mellitus patients and its correlation with glycemic status. International journal of bioassays 3: 3313-3317.

9. Kotwal SK, Laway BA, Shah ZA (2014) Pattern of 25 hydroxy vitamin D status in North Indian people with newly detected type 2 diabetes: A prospective case control study Indian Journal of Endocrinology and Metabolism 18: 726-730.

10. Dutta D, Maisnam I, Shrivastava A, Sinha A, Ghosh S, et al. (2013) Serum vitamin-D predicts insulin resistance in individuals with prediabetes. Indian J Med Res 138: 853-860.

11. Sheth JJ, Shah A, Sheth FJ, Trivedi S, Lele M, et al. (2015) Does vitamin D play a significant role in type 2 diabetes? BMC Endocrine Disorders 15:5.

12. Mohpatra A, Dash P, Mishra P, Mohpatra PC (2014) Serum vitamin D in patients with Type 2 Diabetes Mellitus a cross sectional study with controls. Indian Journal of research 3: 108-12.

13. Bid HK, Konwasr R, Aggarwal CG, Gautam S, Saxena M, et al. (2009) Vitamin D receptor (FolkI, BsmI and TaqI) gene polymorphisms and type 2 diabetes mellitus: A North Indian study. Indian J Med Sci 63: 187-194.

14. Chaudhary S, Thukral A, Tiwari S, Pratyush DD, Singh SK (2013) Vitamin D status of patients with type 2 diabetes and sputum positive pulmonary tuberculosis. Indian J Endocrinol Metab 17: S670-S673.

15. Daga RA, Laway BA, Shah ZA, Mir SA, Kotwal SK, et al. (2012) High prevalence of vitamin $\mathrm{D}$ deficiency among newly diagnosed youth-onset diabetes mellitus in north India. Arq Bras Endocrinol Metabol 56: 423-428.

16. Doddamani GB, Boke U, Kora S, Chickmath R (2013) Serum Vitamin D Levels in Newly Detected Type 2 Diabetes Mellitus. Sch J App Med Sci 1: 786-788. 
Citation: Asegaonkar SB (2016) Vitamin D and Type 2 Diabetes Mellitus: Indian Perspectives. J Diabetic Complications Med 1: 110. doi:10.4172/ jdcm. 1000.110

Page 4 of 4

17. Bajaj AH, Gadre S, Sukumaran S, Vidhate D (2015) Correlation of Vitamin D deficiency with Type 2 diabetes and metabolic traits in the Indian population. Int J Basic Clin Pharmacol 4: 1224-1227.

18. Latha PJ, Kirubharan SS (2015) Association of vitamin D levels with fasting plasma glucose in type 2 Diabetic patients. Journal of Evidence based Medicine and Healthcare 2: 6073-6080.

19. Tandon VR, Sharma S, Mahajan S, Raina K, Mahajan A, et al. (2014) Prevalence of vitamin D deficiency among Indian menopausal women and its correlation with diabetes: A first Indian cross sectional data. J Mid-life health 5: 121-125.

20. Kumar H, Singh VB, Meena BL, Chandra S, single R, et al. (2015) Correlation of Vitamin D level with glycemic control in type 2 diabetes mellitus Sch. J App Med Sci 3: 2277-2283.

21. Agarwal N, Mithal A, Kaur P, Dhingra V, Godbole MM, et al. (2014) Vitamin D and insulin resistance in postmenopausal Indian women. J Endocrinol Metab 18: 89-93.

22. Ramachandran A, Snehalatha C, Mary S, Mukesh B, Bhaskar AD, et al. (2006) The Indian Diabetes Prevention Programme shows that lifestyle modification and metformin prevent type 2 diabetes in Asian Indian subjects with impaired glucose tolerance (IDPP-1). Diabetologia 49 : 289-297.

23. Kota SK, Jammula S, Kota SK, Tripathy PR, Panda S, et al. (2011) Effect of vitamin $\mathrm{D}$ supplementation in type 2 diabetes patients with pulmonary tuberculosis. Diabetes \& Metabolic Syndrome: Clinical Research \& Reviews 5: 85-89.

24. Takiishi T, Gysemans C, Bouillon R, Mathieu C (2010) Vitamin D and diabetes. Endocrinol Metab Clin North Am 39: 419-446.

25. Cigolini M, Iagulli MP, Miconi V, Galiotto M, Lombardi S, et al. (2006) Serum 25-hydroxyvitamin D3 concentrations and prevalence of cardiovascular disease among type 2 diabetic patients. Diabetes Care 29: 722-724.

26. Lorenti CS, Brennan SL, Sanders KM, Neale RE, Lucas RM, et al. (2014) Shining the light on Sunshine: a systematic review of the influence of sun exposure on type 2 diabetes mellitus-related outcomes. Clin Endocrinol (Oxf) 81: 799-811.

27. Londhey V (2011) Vitamin D Deficiency: Indian Scenario JAPI 59: 695-696.

28. Shaha VN, Mohan V (2015) Diabetes in India: what is different? Diabetes and the endocrine pancreas II 22: 283-289.

29. Savastano S, Somma CD, Colao A (2013) Vitamin-D \& prediabetes: a promising ménage in the Indian Scenario. Indian J Med Res 138: 829-830.

30. Pittas A, Lau J, Hu F, Hughes BD (2007) The role of vitamin D and calcium in type 2 diabetes. A systematic review and meta-analysis. J Clin Endocrinol Metab 92: 2017-2029. 